\title{
Phylogenetic taxonomy of the family Chlorobiaceae on the basis of 16S rRNA and fmo (Fenna- Matthews-Olson protein) gene sequences
}

\author{
Johannes F. Imhoff
}

Correspondence

Johannes F. Imhoff

jimhoff@ifm.uni-kiel.de

\section{Introduction}

The green sulfur bacteria, represented by the family Chlorobiaceae, form a branch of bacteria that is phylogenetically distinct from other main phylogenetic lines, and is therefore treated as a separate phylum in Bergey's Manual of Systematic Bacteriology (Overmann, 2001). Traditionally, the taxonomic classification of these bacteria is based on morphological and easily recognizable phenotypic properties (Pfennig, 1989; Pfennig \& Overmann, 2001a, b); such characteristic properties include cell morphology, pigment

Published online ahead of print on 6 December 2002 as DOI 10.1099/ ijs.0.02403-0.

Abbreviations: BChl, bacteriochlorophyll; fmo, Fenna-Matthews-Olson. composition and absorption spectra, and metabolic properties. In particular, (i) the formation of gas vesicles has been used to distinguish between genera; (ii) brown-coloured forms have been distinguished as species from their greencoloured counterparts, and are distinct in their bacteriochlorophyll and carotenoid compositions; and (iii) subspecies were recognized on the basis of utilization of thiosulfate as a photosynthetic electron donor. Although these properties are easily recognizable and have allowed a clear phenotypic differentiation, they are not in accord with the phylogenetic relationship of these bacteria (Figueras et al., 1997; Overmann \& Tuschak, 1997). Therefore, in a systematic taxonomy of green sulfur bacteria based on phylogenetic relationships, they have only very limited relevance. 
Recently, phylogenetic relationships of green sulfur bacteria were established by using 16S rRNA and fmo (FennaMatthews-Olson protein, FMO protein) gene sequences, including important signatures of amino acid and nucleotide sequences (Alexander et al., 2002). The congruent phylogenetic relationships found with two independent gene sequences provide a solid basis for the phylogeny of these bacteria, and for a phylogeny-based taxonomy. A preliminary discussion of taxonomic consequences for the green sulfur bacteria and some proposals were presented previously (Imhoff, 1999; Alexander et al., 2002). Based on these data, some basic taxonomic changes are proposed to establish a phylogenetic system of classification. Genera and species of the green sulfur bacteria are defined, and most available strains are reassigned.

\section{Organisms}

The following taxonomic proposals consider strains and species assigned to the genera Chlorobium, Prosthecochloris and Pelodictyon. Altogether, 15 species and subspecies of these three genera are known (Gorlenko, 2001; Heising et al., 1999; Pfennig \& Overmann, 2001a, b), and both $16 \mathrm{~S}$ rRNA and fmo gene sequence information is available for 10 of the type strains. Additional 16S rDNA sequences of a newly described species ('Chlorobium ferrooxidans') and two species where type strains have been lost (Pelodictyon clathratiforme and Chlorobium chlorovibrioides) are also available (Table 1). In addition, fmo gene sequences have been determined for 17 non-type strains (Alexander et al., 2002), and a larger number of $16 \mathrm{~S}$ rDNA sequences is available (Figueras et al., 1997; Overmann \& Tuschak, 1997; Alexander et al., 2002).

Type strain material from Pelodictyon phaeum and Prosthecochloris phaeoasteroidea did not exist, and neither $16 \mathrm{~S}$ rRNA nor fmo gene sequence information was available for either species; therefore, they are not considered in the following. Because of the lack of type strains, Ancalochloris perfilievii and 'Clathrochloris sulfurica' (for which no species description has been published, but a $16 \mathrm{~S}$ rDNA sequence is available; Witt et al., 1989) are not included in the following considerations.

Chloroherpeton thalassium forms a clearly separate phylogenetic line from the species and genera discussed here. It represents a well-established genus and species, and does not need to be included in the following considerations.

\section{Phylogenetic results}

The phylogenetic studies revealed almost-identical grouping in trees constructed from $16 \mathrm{~S}$ rDNA and fmoA sequences, and suggest a largely congruent evolution of FMO and $16 \mathrm{~S}$ rDNA (Alexander et al., 2002). This is quite remarkable, and strongly supports the 16S rDNA-based phylogeny of these bacteria. The assignment of strains into major phylogenetic groups is further supported by characteristic signatures in the amino acid sequence of the FMO protein (Alexander et al., 2002). Their phylogenetic relationship and separation into groups is depicted in Fig. 1, which shows the 16S rDNA-based relationships between the strains compared to those based on fmo sequences, and in Table 1.

The phylogenetic grouping of the green sulfur bacteria is not in accord with their current classification, or with the current assignment of species to genera and of strains to species. Three examples demonstrate this: (i) species of the genus Chlorobium appear in all major groups, and those of the genus Pelodictyon in two of them (Table 1); (ii) strains of several species, including Chlorobium limicola, Chlorobium phaeobacteroides, Chlorobium vibrioforme and Chlorobium phaeovibrioides, appear in at least two of the major groups (Table 1); (iii) Chlorobium limicola subsp. thiosulfatophilum and Chlorobium vibrioforme subsp. thiosulfatophilum, as defined by their type strains, are different from their reference species at the genus level (Table 1).

From analysis of all available information, it becomes obvious that besides $16 \mathrm{~S}$ rRNA and other gene sequences, the DNA G $+\mathrm{C}$ content is relevant for species recognition. It is difficult at present to find phenotypic properties that can be determined easily, and that are in agreement with the genetic relationship between the green sulfur bacteria. Properties that are significant for taxonomic classification include the requirement for salt, and the composition of lipids and fatty acids may also prove to be useful (Imhoff, 1988; Imhoff \& Bias-Imhoff, 1995). However, properties that have been used so far for classification (pigment composition, presence of gas vesicles, thiosulfate utilization and the characteristic formation of cell aggregates) are apparently of very limited significance in a phylogenetic system of the green sulfur bacteria.

Four major groups of species of green sulfur bacteria were recognized by Alexander et al. (2002), and were proposed as a basis for the definition of genera. Only two of these groups currently have recognized type species: Chlorobium limicola and Pelodictyon clathratiforme (group 3; Alexander et al., 2002) and Prosthecochloris aestuarii (group 1; Alexander et al., 2002). Group 4 is represented by a number of strains and species presently assigned to the genus Chlorobium, although phylogenetically distant from the type species Chlorobium limicola and the group of strains that clusters with this species. Consequently, the bacteria of group 4 need to be assigned to a novel genus, for which the name Chlorobaculum gen. nov. is proposed.

Although the consideration of sequence signatures of the FMO protein made the separation of groups 2 and 3 of Alexander et al. (2002) both possible and plausible, these two groups are quite closely related and the clear separation of the strains poses problems. According to 16S rRNA gene sequences, the type strains of Chlorobium phaeovibrioides, Chlorobium vibrioforme subsp. thiosulfatophilum and Pelodictyon luteolum form the coherent cluster of group 2. In particular, subgroup 3a (which includes Chlorobium phaeobacteroides and Pelodictyon phaeoclathratiforme) has an intermediate position between the two groups, and is 
Table 1. Names and some properties of species and strains of the genera Chlorobium, Prosthecochloris and Chlorobaculum

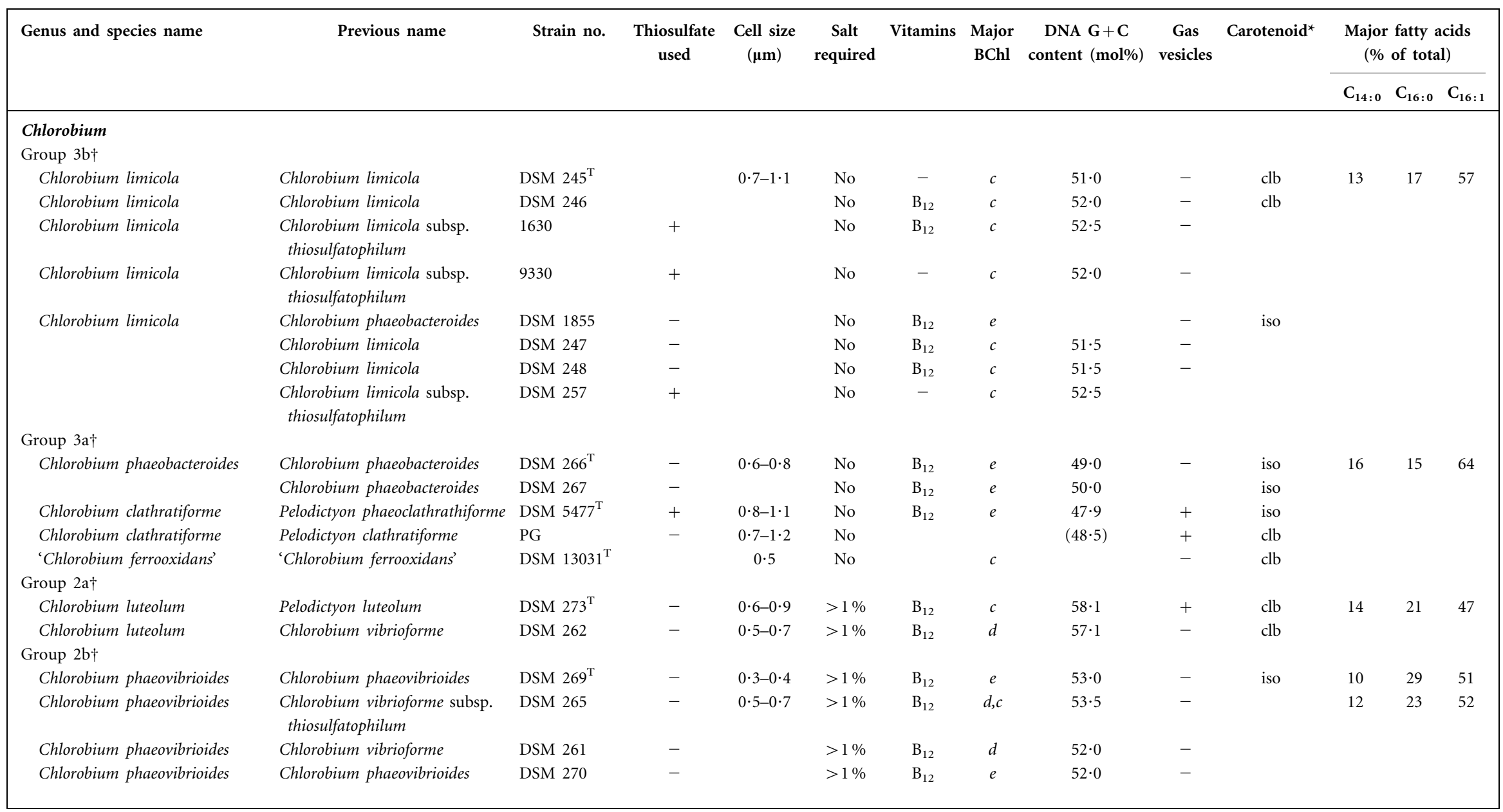


Table 1. cont.

\begin{tabular}{|c|c|c|c|c|c|c|c|c|c|c|c|c|c|}
\hline \multirow[t]{2}{*}{ Genus and species name } & \multirow[t]{2}{*}{ Previous name } & \multirow[t]{2}{*}{ Strain no. } & \multirow[t]{2}{*}{$\begin{array}{c}\text { Thiosulfate } \\
\text { used }\end{array}$} & \multirow[t]{2}{*}{$\begin{array}{l}\text { Cell size } \\
(\mu \mathrm{m})\end{array}$} & \multirow[t]{2}{*}{$\begin{array}{c}\text { Salt } \\
\text { required }\end{array}$} & \multirow[t]{2}{*}{ Vitamins } & \multirow[t]{2}{*}{$\begin{array}{l}\text { Major } \\
\text { BChl }\end{array}$} & \multirow[t]{2}{*}{$\begin{array}{c}\text { DNA G+C } \\
\text { content }(\mathrm{mol} \%)\end{array}$} & \multirow[t]{2}{*}{$\begin{array}{c}\text { Gas } \\
\text { vesicles }\end{array}$} & \multirow[t]{2}{*}{ Carotenoid $^{*}$} & \multicolumn{3}{|c|}{$\begin{array}{l}\text { Major fatty acids } \\
\quad(\% \text { of total })\end{array}$} \\
\hline & & & & & & & & & & & $\mathrm{C}_{14: 0}$ & $\mathrm{C}_{16: 0}$ & $\mathrm{C}_{16: 1}$ \\
\hline \multicolumn{14}{|l|}{ Prosthecochloris } \\
\hline \multicolumn{14}{|l|}{ Group $1 \dagger$} \\
\hline Prosthecochloris aestuarii & Prosthecochloris aestuarii & DSM $271^{\mathrm{T}}$ & - & $0 \cdot 5-0 \cdot 7$ & $2-5 \%$ & $\mathrm{~B}_{12}$ & $c$ & $52-56 \cdot 1$ & - & $\mathrm{clb}$ & & & \\
\hline Prosthecochloris sp. & Prosthecochloris aestuarii & $2 \mathrm{~K}$ & - & & Yes & & & & - & & & & \\
\hline Prosthecochloris vibrioformis & Chlorobium vibrioforme & DSM $260^{\mathrm{T}}$ & - & $0 \cdot 5-0 \cdot 7$ & $>1 \%$ & $\mathrm{~B}_{12}$ & $d, c$ & $53 \cdot 5$ & - & $\mathrm{clb}$ & & & \\
\hline Prosthecochloris vibrioformis & Chlorobium phaeovibrioides & DSM 1678 & - & & $>1 \%$ & & $e$ & & - & & & & \\
\hline Prosthecochloris vibrioformis & Chlorobium vibrioforme & CHP 3402 & & & & & & & - & & & & \\
\hline \multicolumn{14}{|l|}{ Chlorobaculum } \\
\hline \multicolumn{14}{|l|}{ Group $4 \mathrm{~b} \dagger$} \\
\hline Chlorobaculum tepidum & Chlorobium tepidum & ATCC $49652^{\mathrm{T}}$ & + & $0 \cdot 6-0 \cdot 8$ & No & & $c$ & $56 \cdot 5$ & - & $\mathrm{clb}$ & & & \\
\hline Chlorobaculum limnaeum & Chlorobium phaeobacteroides & DSM $1677^{\mathrm{T}}$ & - & & No & $\mathrm{B}_{12}$ & $e$ & & - & & & & \\
\hline \multirow{5}{*}{ Chlorobaculum limnaeum } & Chlorobium phaeobacteroides & 1549 & - & & No & & & & - & & & & \\
\hline & Chlorobium limicola & UdG 6040 & & $0 \cdot 8-1 \cdot 0$ & & & $c$ & & - & $\mathrm{clb}$ & & & \\
\hline & Chlorobium limicola & UdG 6042 & & $0 \cdot 8-1 \cdot 0$ & & & $c$ & & - & $\mathrm{clb}$ & & & \\
\hline & Chlorobium limicola & UdG 6045 & & $0 \cdot 7-1 \cdot 0$ & & & $c$ & & - & $\mathrm{clb}$ & & & \\
\hline & Chlorobium limicola & UdG 6038 & & $0 \cdot 7-1 \cdot 0$ & & & $c$ & & - & $\mathrm{clb}$ & & & \\
\hline Chlorobaculum thiosulfatiphilum & $\begin{array}{l}\text { Chlorobium limicola subsp. } \\
\text { thiosulfatophilum }\end{array}$ & DSM $249^{\mathrm{T}}$ & + & $0 \cdot 7-1 \cdot 0$ & No & - & $c$ & $58 \cdot 1$ & - & $\mathrm{clb}$ & 21 & 10 & 43 \\
\hline Chlorobaculum thiosulfatiphilum & $\begin{array}{l}\text { Chlorobium limicola subsp. } \\
\text { thiosulfatophilum }\end{array}$ & 1430 & + & & No & - & $c$ & $58 \cdot 1$ & - & & & & \\
\hline \multicolumn{14}{|l|}{ Group $4 \mathrm{a} \dagger$} \\
\hline Chlorobaculum parvum & $\begin{array}{l}\text { Chlorobium vibrioforme subsp. } \\
\text { thiosulfatophilum }\end{array}$ & DSM $263^{\mathrm{T}}$ & + & $0 \cdot 7-1 \cdot 1$ & $>1 \%$ & & $d$ & $56 \cdot 6$ & - & $\mathrm{clb}$ & 24 & 23 & 43 \\
\hline Chlorobaculum parvum & $\begin{array}{l}\text { Chlorobium vibrioforme subsp. } \\
\text { thiosulfatophilum }\end{array}$ & NCIB 8346 & + & & $>1 \%$ & & $d$ & $56 \cdot 1$ & - & & & & \\
\hline 'Chlorobaculum chlorovibrioides' & Chlorobium chlorovibrioides & UdG 6026 & - & $0 \cdot 3-0 \cdot 4 \dagger$ & $2-3 \%$ & $\mathrm{~B}_{12}$ & $c$ & $54 \cdot 0$ & - & $\mathrm{clb}$ & & & \\
\hline 'Chlorobaculum chlorovibrioides' & Chlorobium vibrioforme & UdG 6043 & & $0 \cdot 7-0 \cdot 8$ & $5 \%$ & & $c$ & & - & $\mathrm{clb}$ & & & \\
\hline
\end{tabular}

${ }^{*} \mathrm{clb}$, Chlorobactene; iso, isorenieratene.

$\dagger$ According to Alexander et al. (2002). 


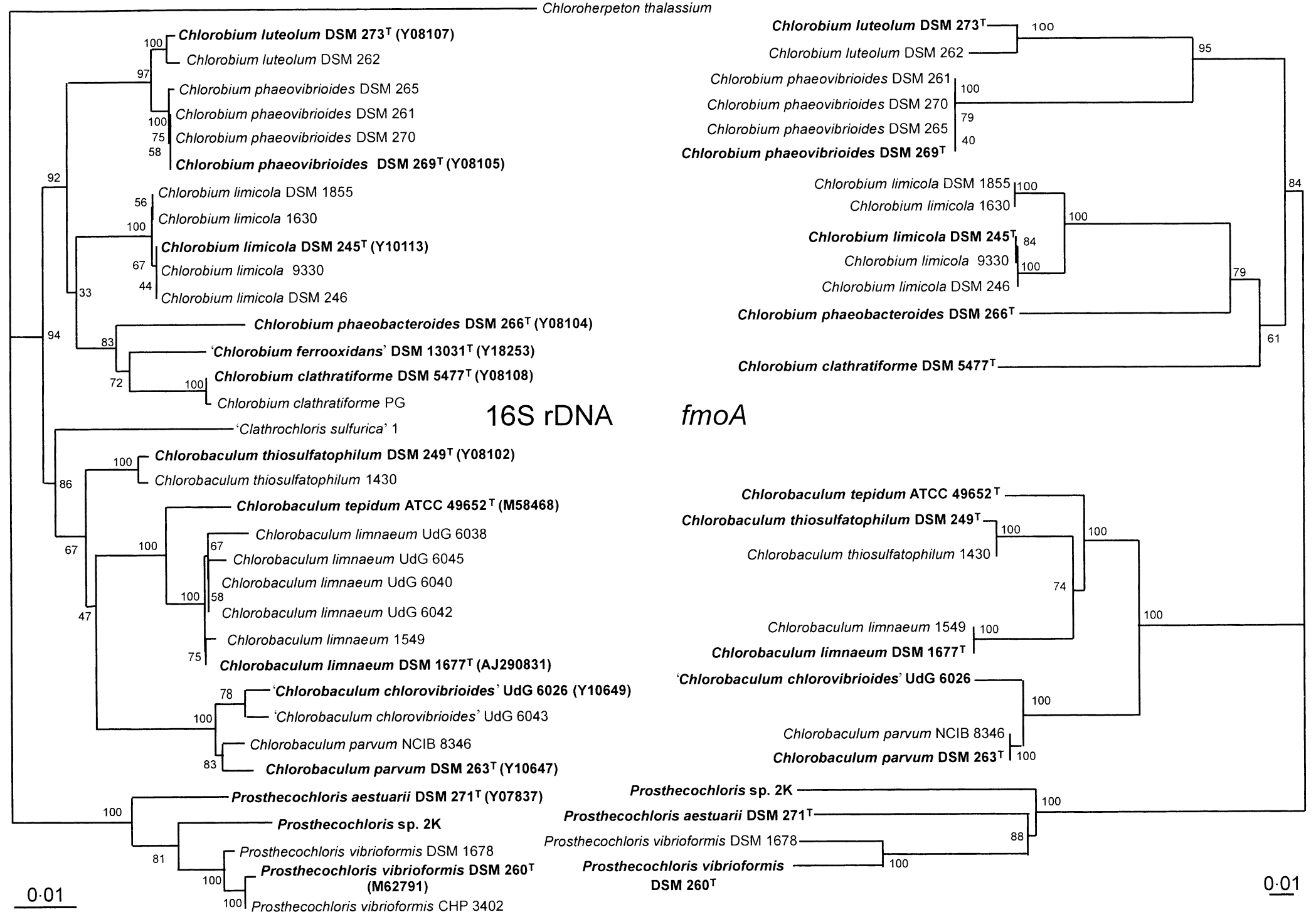

Chlorobium luteolum DSM 273 Chlorobium phaeovibrioides DSM 270

SM 269'T Y08105)

Chlorobium limicola DSM 246 
closely related to Pelodictyon luteolum on the basis of fmo gene sequences. Even if phenotypic information (such as cell morphology, salt requirement and DNA G + C content) were available to distinguish between groups 2 and 3, it is proposed that the species of both groups should be classified in a single genus. According to the presence of the type strain of the type species, Chlorobium limicola DSM $245^{\mathrm{T}}$, in group 3 and the priority of Chlorobium over Pelodictyon, Chlorobium will be the genus name of this group. The $16 \mathrm{~S}$ rDNA sequence similarities of more than $95 \%$ between strains of this genus, as defined by phylogenetic groups 2 and 3, are in line with current practice, by which separation into genera occurs below $95 \%$ similarity in most cases. Consequently, Chlorobium will continue to be a heterogeneous genus, in which different subgroups can be distinguished on the basis of properties such as cell form and size, DNA G + C content and salt response, but also on the basis of genetic sequence information. Most of the currently used species names will be maintained, because the majority of species and strains of these two groups were previously included in the genus Chlorobium.

\section{Descriptions of genera and species}

According to their phylogenetic relationship and the proposed phylogenetic definition of the genera, several species descriptions need to be emended, and a large number of strains need to be reassigned to different species. Properties of the species and genera are given in Table 2. The basic information for strain and species assignment and some properties are shown in Table 1. Proposed new and old names are listed in this table and demonstrate the problematic situation of the current state of the taxonomy. Incorrect species names assigned to a great number of strains of green sulfur bacteria create a highly confusing situation, and limit the transparency of comparative scientific work on these bacteria (particularly if species names but not strain numbers are given, as in many publications).

Because of the priority of types in taxonomy, the defined types set the frame for the following considerations. Chlorobium is the type genus of the Chlorobiaceae (Trüper, 1976). Chlorobium limicola, Pelodictyon clathratiforme and Prosthecochloris aestuarii are the type species of the genera that are considered for the present discussion (Gorlenko, 2001; Pfennig \& Overmann, 2001a, b). Therefore, the type strains of Chlorobium limicola (DSM $245^{\mathrm{T}}$ ) and of Prosthecochloris aestuarii (DSM 271 ${ }^{\mathrm{T}}$ ) form the basis of the genera Chlorobium and Prosthecochloris, which are at a phylogenetic distance that clearly allows their assignment to different genera. Pelodictyon clathratiforme is phylogenetically closely related to Chlorobium limicola, and must therefore be regarded as a Chlorobium species. Because Pelodictyon clathratiforme is the type species of this genus, according to Rule 37a of the Bacteriological Code (1990 Revision) (Lapage et al., 1992), the consequence of this transfer is that the other Pelodictyon species must also be assigned to another genus (see below).

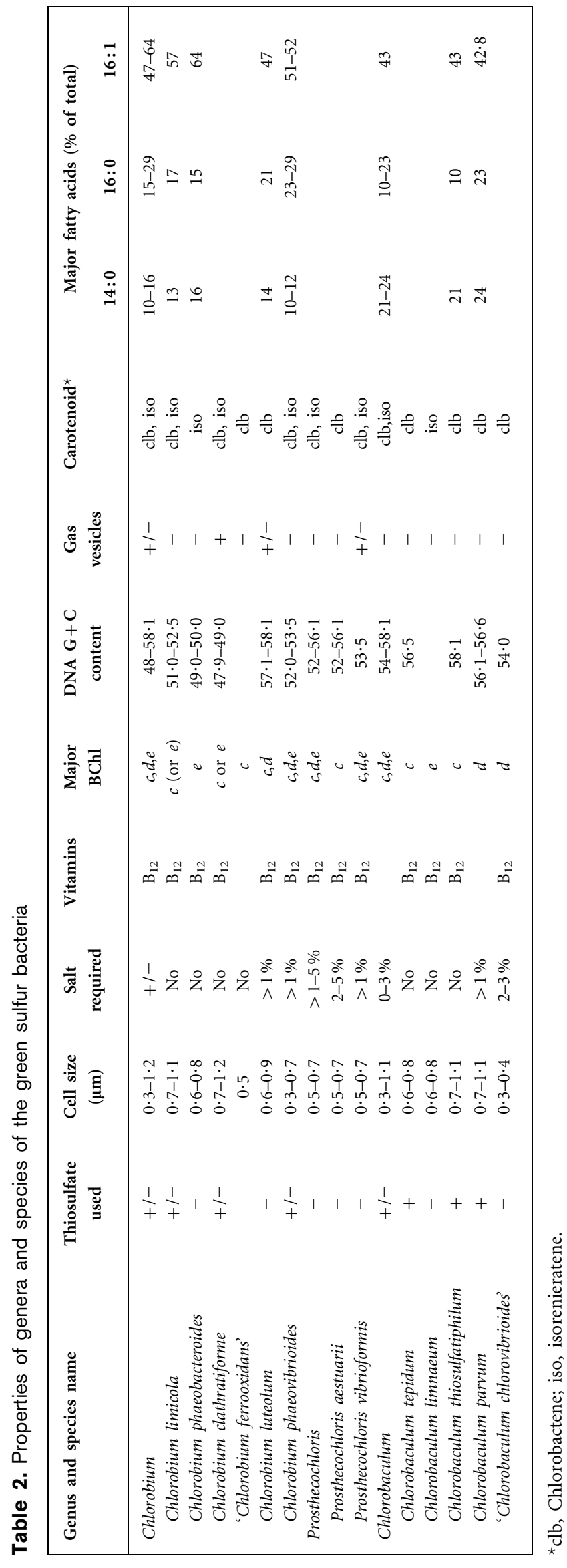




\section{Emended description of the genus Chlorobium}

The genus Chlorobium comprises green sulfur bacteria with vibrioid or rod-shaped cells that occur singly or in cell aggregates. Some species and strains may contain gas vesicles. Cell size ranges from $0 \cdot 3$ to $1 \cdot 2 \mu \mathrm{m}$ in width. As photosynthetic pigments, either bacteriochlorophyll (BChl) $c$ and $d$ or $\mathrm{BChl} e$ is present. The former are accompanied by carotenoids of the chlorobactene series, and the latter by those of the isorenieratene series. Rod-shaped cells have a cell width of $0 \cdot 6-1 \cdot 2 \mu \mathrm{m}$, DNA G+C content of $47 \cdot 9$ $52.5 \mathrm{~mol} \%$ and do not require salt; vibrioid species have a cell width of $0 \cdot 3-0 \cdot 9 \mu \mathrm{m}$, DNA G $+\mathrm{C}$ content of $52-$ $58.1 \mathrm{~mol} \%$ and require low amounts of salt. Most strains require vitamin $B_{12}$ as a growth factor. The fatty acid composition is characterized by approximately $10-16 \%$ $\mathrm{C}_{14: 0}$ and 57-64\% $\mathrm{C}_{16: 1}$. The genus comprises strains and species that belong phylogenetically to groups 2 and 3 of the green sulfur bacteria, according to Alexander et al. (2002). Photolithoautotrophic growth occurs under anoxic conditions in the light, with reduced sulfur compounds such as sulfide and elemental sulfur as electron donors. Thiosulfate and hydrogen may be used. During oxidation of sulfide, elemental sulfur is transiently deposited outside cells. Final oxidation product is sulfate. In the presence of sulfide and bicarbonate, simple organic substrates are photoassimilated. Obligately phototrophic and strictly anaerobic. The DNA G + C content is $47 \cdot 9-58 \cdot 1 \mathrm{~mol} \%$ (Bd).

The type species is Chlorobium limicola Nadson 1906, 190.

\section{Emended description of Chlorobium limicola}

The species description is as given by Pfennig \& Overmann (2001a), with the following modifications. Cells are rodshaped, $0 \cdot 7-1 \cdot 1 \mu \mathrm{m}$ wide and non-motile. Photosynthetic pigments are $\mathrm{BChl} c$ with chlorobactene as the major carotenoid, or in some strains, $\mathrm{BChl} e$ with isorenieratene. Photoautotrophic growth occurs with sulfide and sulfur as photosynthetic electron donors; molecular hydrogen and thiosulfate may be used. In the presence of sulfide and bicarbonate, some simple organic compounds are photoassimilated. Freshwater bacteria without a requirement for sodium chloride. The DNA G $+\mathrm{C}$ content is $51-52 \cdot 5 \mathrm{~mol} \%$.

The type strain is DSM $245^{\mathrm{T}}$. The GenBank/EMBL accession number for the $16 \mathrm{~S}$ rDNA sequence of the type strain is Y10113.

Comments. This species is a representative of group 3, according to Alexander et al. (2002). In addition to the type strain DSM $245^{\mathrm{T}}$, strains clearly assigned to this species are 1630, 9330, DSM 246 and DSM 1855. These include two strains that were formerly known as Chlorobium limicola subsp. thiosulfatophilum (strains 1630 and 9330) and one strain formerly assigned to Chlorobium phaeobacteroides (DSM 1855). Because of the conflicting situation with other strains known as Chlorobium limicola subsp. thiosulfatophilum that are no longer considered to belong to the genus Chlorobium (see below), it is proposed to abandon the use of subspecies names for thiosulfate-utilizing strains of this and other species of the green sulfur bacteria. Thiosulfate utilization is considered to be a property of some of the strains of Chlorobium limicola (strains 1630, 9330 and DSM 257). Although the DNA G + C content and some other properties of strains DSM 247, DSM 248 and DSM 257 fit with the properties of Chlorobium limicola, sequence data are lacking and therefore their assignment to Chlorobium limicola is likely but not secure. Excluded from this species are all strains that have a DNA G $+\mathrm{C}$ content of $>54 \mathrm{~mol} \%$ and belong to group 4 (Table 1). Strains UdG 6051, UdG 6046 and UdG 6047 (known as Chlorobium phaeobacteroides; Figueras et al., 1997) are genetically related to Chlorobium limicola, but further studies are necessary to determine their relationship to Chlorobium limicola.

\section{Emended description of Chlorobium phaeobacteroides}

The species description is as given by Pfennig \& Overmann (2001a). This bacterium is a freshwater species without a salt requirement and with a DNA G $+\mathrm{C}$ content of 49-50 mol\%.

The type strain is DSM $266^{\mathrm{T}}$. The GenBank/EMBL accession number for the 16S rDNA sequence of the type strain is Y08104.

Comments. This species is a representative of group 3, according to Alexander et al. (2002). The type strain of Chlorobium phaeobacteroides, DSM $266^{\mathrm{T}}$, forms a distinct phylogenetic lineage and is the only strain representing this species. The lack of sequence information does not allow the secure assignment of strain DSM 267 to this species, although its DNA G $+\mathrm{C}$ content of $50 \cdot 0 \mathrm{~mol} \%$ is close to that of the type strain $(49 \cdot 0 \mathrm{~mol} \%)$. Other strains known as Chlorobium phaeobacteroides must be excluded from this species, and are assigned to Chlorobium limicola (DSM 1855) and to Chlorobaculum limnaeum (strains 1549 and DSM 1677, see below).

\section{Emended description of 'Chlorobium ferrooxidans'}

The species description is as given by Heising et al. (1999). The type strain is DSM $13031^{\mathrm{T}}$. The GenBank/EMBL accession number for the 16S rDNA sequence of the type strain is Y18253.

Comments. This species is a representative of group 3, according to Alexander et al. (2002). It is related to, but distinct from, Chlorobium phaeobacteroides.

\section{Description of Chlorobium clathratiforme comb. nov.}

Basonym: Pelodictyon clathratiforme (Szafer 1911) Lauterborn 1913 (Approved Lists 1980). 
The species description is as given by Pfennig \& Overmann (2001b) for Pelodictyon clathratiforme and Pelodictyon phaeoclathratiforme. Cells are rod-shaped, non-motile, $0 \cdot 7-1 \cdot 2 \mu \mathrm{m}$ wide, produce gas vesicles and characteristically form three-dimensional nets. Colour of cell suspensions is green or brown, and photosynthetic pigments are BChl $c$ with chlorobactene as the major carotenoid in green strains and $\mathrm{BChl} e$ with isorenieratene as the major carotenoid in brown strains. Photoautotrophic growth occurs with sulfide and sulfur as photosynthetic electron donors; thiosulfate may be used. In the presence of sulfide and bicarbonate, some simple organic compounds are photoassimilated. Vitamin $B_{12}$ is required for growth. Freshwater bacteria without a requirement for $\mathrm{NaCl}$. The DNA G + C content is $48-49 \mathrm{~mol} \%$.

The type strain is DSM $5477^{\mathrm{T}}=\mathrm{BU} 1^{\mathrm{T}}$. The GenBank/EMBL accession number for the $16 \mathrm{~S}$ rDNA sequence of the type strain is Y08108.

Comments. This species is a representative of group 3, according to Alexander et al. (2002). The 16S rDNA sequences of Pelodictyon clathratiforme PG and Pelodictyon phaeoclathratiforme DSM $5477^{\mathrm{T}}$ are almost identical, and closely related to those of 'Chlorobium ferrooxidans' and Chlorobium phaeobacteroides. As already proposed (Imhoff, 1999), both species are transferred to the genus Chlorobium. Because Pelodictyon clathratiforme is the type species of the genus Pelodictyon, all members of the genus must be transferred to another genus. Because the different pigmentation, which was the main distinguishing feature between Pelodictyon clathratiforme and Pelodictyon phaeoclathratiforme, has been disregarded as a speciesdeterminative property, and due to $16 \mathrm{~S}$ rDNA sequence identity and lack of a type culture of Pelodictyon clathratiforme, it is proposed to combine both species and to consider strain DSM $5477^{\mathrm{T}}$ as the type strain of Chlorobium clathratiforme comb. nov.

\section{Emended description of Chlorobium phaeovibrioides}

The species description is as given by Pfennig \& Overmann (2001a), with the following modifications. Cells are curved rods or vibrioid, $0 \cdot 3-0 \cdot 7 \mu \mathrm{m}$ wide, non-motile and occur as single cells. Colour of cell suspensions is green or brown, and photosynthetic pigments are BChl $d$ (occasionally also BChl c) with chlorobactene as the major carotenoid in green strains, and $\mathrm{BChl} e$ with isorenieratene as the major carotenoid in brown strains. Photoautotrophic growth occurs with sulfide and sulfur as photosynthetic electron donors; thiosulfate may be used by some strains. In the presence of sulfide and bicarbonate, some simple organic compounds are photoassimilated. Vitamin $B_{12}$ is required for growth. Brackish water and marine bacteria that require at least $1 \% \mathrm{NaCl}$. The DNA G $+\mathrm{C}$ content is $52-53.5 \mathrm{~mol} \%$.

The type strain is DSM $269^{\mathrm{T}}$. The GenBank/EMBL accession number for the $16 \mathrm{~S}$ rDNA sequence of the type strain is Y08105.

Comments. This species is a representative of group 2, according to Alexander et al. (2002). The type strain of Chlorobium phaeovibrioides, DSM $269^{\mathrm{T}}$, forms a distinct phylogenetic lineage which allows its recognition as a separate species. Almost-identical sequences of the $16 \mathrm{~S}$ rRNA and fmo genes, salt requirement, similar fatty acid composition and DNA G+C contents of 52.0$53.5 \mathrm{~mol} \%$ strongly support the inclusion of Chlorobium phaeovibrioides DSM 270, Chlorobium vibrioforme DSM 261 and Chlorobium vibrioforme subsp. thiosulfatophilum DSM 265 into this species. Strain DSM 265, which was previously considered as the type strain of Chlorobium vibrioforme subsp. thiosulfatophilum, loses type strain status and the name becomes a synonym of Chlorobium phaeovibrioides. Other strains of this subspecies must be assigned to different species (see below). It is particularly striking that the four strains now classified as Chlorobium phaeovibrioides were previously assigned to four different species and subspecies. Further studies are needed to prove the taxonomic status of Chlorobium phaeovibrioides UdG 6035, which is related to this species.

\section{Description of Chlorobium luteolum comb. nov.}

Basonym: Pelodictyon luteolum (Schmidle 1901) Pfennig and Trüper 1971 (Approved Lists 1980).

The species description is as given by Pfennig \& Overmann (2001b) for Pelodictyon luteolum, with the following modifications. Cells are straight or curved rods or vibrioid, $0 \cdot 6-0 \cdot 9 \mu \mathrm{m}$ wide, non-motile and may form gas vesicles. Colour of cell suspensions is green, and photosynthetic pigments are BChl $c$ and $d$ with chlorobactene as the major carotenoid. Photoautotrophic growth occurs with sulfide and sulfur as photosynthetic electron donors. In the presence of sulfide and bicarbonate, some simple organic compounds are photoassimilated. Vitamin $\mathrm{B}_{12}$ is required for growth. Brackish water and marine bacteria that require at least $1 \% \mathrm{NaCl}$. The DNA $\mathrm{G}+\mathrm{C}$ content is $57 \cdot 1-58 \cdot 1 \mathrm{~mol} \%$.

The type strain is DSM $273^{\mathrm{T}}$. The GenBank/EMBL accession number for the $16 \mathrm{~S}$ rDNA sequence of the type strain is Y08107.

Comments. This species is a representative of group 2, according to Alexander et al. (2002). As outlined above, Pelodictyon luteolum must be assigned to another genus. As proposed by Imhoff (1999) and due to its phylogenetic relationship, the type strain of Pelodictyon luteolum, DSM $273^{\mathrm{T}}$, is transferred to the genus Chlorobium and becomes the type strain of the novel species Chlorobium luteolum. Almost-identical $16 \mathrm{~S}$ rRNA and fmo gene sequences, together with a similar DNA G +C content $(57 \cdot 1 \mathrm{~mol} \%$, compared to $58 \cdot 1 \mathrm{~mol} \%$ of the type strain) strongly 
support the inclusion of Chlorobium vibrioforme DSM 262 in this species.

\section{Emended description of the genus Prosthecochloris}

The genus Prosthecochloris comprises green sulfur bacteria with spherical to ovoid, vibrioid or rod-shaped cells that develop as single cells and may form non-branching prosthecae. Some species and strains may contain gas vesicles. The cell size ranges from 0.5 to $0.8 \mu \mathrm{m}$ in width. As photosynthetic pigments, either $\mathrm{BChl} c$ and $d$ or BChl $e$ is present. The former are accompanied by carotenoids of the chlorobactene series, the latter by those of the isorenieratene series. Salt is required for growth. Vitamin $\mathrm{B}_{12}$ is a growth factor. The genus comprises those strains and species that belong phylogenetically to group 1 of the green sulfur bacteria, according to Alexander et al. (2002). Photolithoautotrophic growth occurs under anoxic conditions in the light, with reduced sulfur compounds such as sulfide and elemental sulfur as electron donors. During oxidation of sulfide, elemental sulfur is transiently deposited outside cells. Final oxidation product is sulfate. In the presence of sulfide and bicarbonate, simple organic substrates are photoassimilated. Obligately phototrophic and strictly anaerobic. The DNA G $+\mathrm{C}$ content is $52 \cdot 0-$ $56 \cdot 1 \mathrm{~mol} \%(\mathrm{Bd})$.

The type species is Prosthecochloris aestuarii Gorlenko 1970, 148.

\section{Emended description of Prosthecochloris aestuarii}

The species description is as given by Gorlenko (2001). The type strain is DSM $271^{\mathrm{T}}$. The GenBank/EMBL accession number for the $16 \mathrm{~S}$ rDNA sequence of the type strain is Y07837.

Comments. The strain known as Prosthecochloris aestuarii $2 \mathrm{~K}$ is genetically different from the type strain of Prosthecochloris aestuarii, to a degree that indicates species differentiation $(97 \cdot 3 \% 16 \mathrm{~S}$ rDNA sequence similarity and significant differences in sequence signatures). It should be classified as a novel species of the genus Prosthecochloris. However, as no pure culture is presently available, this description is postponed.

\section{Description of Prosthecochloris vibrioformis comb. nov.}

Basonym: Chlorobium vibrioforme Pelsh 1936.

The species description is as given by Pfennig \& Overmann (2001a) for Chlorobium vibrioforme, with the following modifications. Cells are curved rods or vibrioid, $0 \cdot 5-0 \cdot 7 \mu \mathrm{m}$ wide, non-motile and occur as single cells. Gas vesicles may be formed. Colour of cell suspensions is green or brown, and photosynthetic pigments are $\mathrm{BChl} d$ (occasionally also $\mathrm{BChl} c$ ) with chlorobactene as the major carotenoid in green strains, and $\mathrm{BChl} e$ with isorenieratene as the major carotenoid in brown strains. Photoautotrophic growth occurs with sulfide and sulfur as photosynthetic electron donors; molecular hydrogen may be used by some strains. In the presence of sulfide and bicarbonate, some simple organic compounds are photoassimilated. Vitamin $B_{12}$ is required for growth by most strains. Brackish water and marine bacteria that require at least $1 \% \mathrm{NaCl}$. The DNA $\mathrm{G}+\mathrm{C}$ content is $53 \cdot 5 \mathrm{~mol} \%$.

The type strain is DSM $260^{\mathrm{T}}$. The GenBank/EMBL accession number for the $16 \mathrm{~S}$ rDNA sequence of the type strain is M62791.

Comments. The type strain of Chlorobium vibrioforme, DSM $260^{\mathrm{T}}$, does not belong to the genus Chlorobium, but is genetically closely related to Prosthecochloris aestuarii. The degree of relatedness justifies its recognition as a species of the genus Prosthecochloris. It is therefore proposed that strain DSM $260^{\mathrm{T}}$ is recognized as the type strain of Prosthecochloris vibrioformis comb. nov. With this transfer, Chlorobium vibrioforme becomes a synonym of Prosthecochloris vibrioformis, and other strains assigned to this species, including subspecies, must be assigned to different species (see Table 1). Sequence similarities of more than $99 \%$ for both the $16 \mathrm{~S}$ rRNA and the fmo genes support the recognition of Chlorobium phaeovibrioides DSM 1678 and Chlorobium vibrioforme CHP 3402 as additional strains of Prosthecochloris vibrioformis.

\section{Description of Chlorobaculum gen. nov.}

Chlorobaculum (Chlo.ro.ba'cu.lum. Gr. adj. chloros green; L. n. baculum rod; N.L. neut. n. Chlorobaculum the green rod).

The genus Chlorobaculum comprises green sulfur bacteria with vibrioid or rod-shaped cells that develop singly. Some species and strains may contain gas vesicles. The cell size ranges from 0.3 to $1 \cdot 1 \mu \mathrm{m}$ in width. Photosynthetic pigments are $\mathrm{BChl} c$ and $d$ or $\mathrm{BChl} e$, with carotenoids of the chlorobactene series in green strains and of the isorenieratene series in brown strains. Sodium chloride may be required for growth. Vitamin $B_{12}$ is required as a growth factor by most species. The fatty acid composition is characterized by approximately $21-25 \% \mathrm{C}_{14: 0}$ and approximately $43 \% \mathrm{C}_{16: 1}$. The genus comprises those strains and species that previously belonged to the genus Chlorobium, but form phylogenetic group 4 of the green sulfur bacteria, according to Alexander et al. (2002). Photolithoautotrophic growth occurs under anoxic conditions in the light, with reduced sulfur compounds such as sulfide, elemental sulfur and thiosulfate as electron donors. During oxidation of sulfide, elemental sulfur is transiently deposited outside cells. Final oxidation product is sulfate. In the presence of sulfide and bicarbonate, simple organic substrates are photoassimilated. Obligately phototrophic and strictly anaerobic. The DNA G $+\mathrm{C}$ content is $54 \cdot 0$ $58 \cdot 1 \mathrm{~mol} \%$ (Bd). 
The type species is Chlorobaculum tepidum comb. nov. (Chlorobium tepidum Wahlund et al. 1996, 1189).

\section{Description of Chlorobaculum tepidum comb. nov.}

Basonym: Chlorobium tepidum Wahlund et al. 1991.

The species description is basically that given by Wahlund et al. (1991) and Pfennig \& Overmann (2001a) for Chlorobium tepidum. It is a moderately thermophilic freshwater species without a salt requirement and with a DNA G $+C$ content of $56 \cdot 5 \mathrm{~mol} \%$.

The type strain is ATCC $49652^{\mathrm{T}}=\mathrm{DSM} 12025^{\mathrm{T}}$. The GenBank/EMBL accession number for the 16S rDNA sequence of the type strain is M58468.

Comments. The type strain of Chlorobium tepidum, ATCC $49652^{\mathrm{T}}$, is phylogenetically distant from all other strains that belong to this group. It is proposed as the type strain of Chlorobaculum tepidum sp. nov.

\section{Description of Chlorobaculum limnaeum sp. nov.}

Chlorobaculum limnaeum (lim.nae'um. Gr. adj. limnaios pertaining to or living in lakes; M.L. neut. adj. limnaeum living in lakes).

Cells are rod-shaped, $0 \cdot 6-0 \cdot 8 \mu \mathrm{m}$ wide and non-motile. Colour of cell suspensions is brown or green, and photosynthetic pigments are $\mathrm{BChl} e$ with isorenieratene as the major carotenoid in brown strains and BChl $c$ with chlorobactene as the major carotenoid in green strains. Photoautotrophic growth occurs with sulfide and sulfur as photosynthetic electron donors; molecular hydrogen may also be used. In the presence of sulfide and bicarbonate, some simple organic compounds are photoassimilated. Freshwater bacteria without a requirement for sodium chloride. Vitamin $\mathrm{B}_{12}$ may be required for growth.

The type strain is DSM $1677^{\mathrm{T}}$. The GenBank/EMBL accession number for the $16 \mathrm{~S}$ rDNA sequence of the type strain is AJ290831.

Comments. Two strains that were known as Chlorobium phaeobacteroides, 1549 and DSM 1677, have almostidentical 16S rRNA and fmo gene sequences and are closely related to Chlorobaculum tepidum. They are phylogenetically distant from the type strain of Chlorobium phaeobacteroides and are assigned to Chlorobaculum limnaeum sp. nov. The strains known as Chlorobium limicola UdG 6038, UdG 6040, UdG 6042 and UdG 6045 have highly similar $16 \mathrm{~S}$ rDNA sequences to the two strains of Chlorobaculum limnaeum, and may be considered as strains of this species. The assignment of strain UdG 6041 requires further study.

\section{Description of Chlorobaculum thiosulfatiphilum} sp. nov.

Chlorobaculum thiosulfatiphilum (thi.o.sul.fa.ti'phi.lum. N.L. n. thiosulfas, -atis thiosulfate; Gr. adj. philos loving; N.L. neut. n. thiosulfatiphilum thiosulfate-loving).

Cells are rod-shaped, $0 \cdot 7-1 \cdot 1 \mu \mathrm{m}$ wide, non-motile and occur as single cells. Colour of cell suspensions is green, and photosynthetic pigments are $\mathrm{BChl} c$ with chlorobactene as the major carotenoid. Photoautotrophic growth occurs with sulfide, sulfur and thiosulfate as photosynthetic electron donors; molecular hydrogen also may be used. In the presence of sulfide and bicarbonate, some simple organic compounds are photoassimilated. Freshwater bacteria without a requirement for sodium chloride. Vitamin $B_{12}$ may be required for growth. The DNA G $+C$ content is $58 \cdot 1 \mathrm{~mol} \%$.

The type strain is DSM $249^{\mathrm{T}}$. The GenBank/EMBL accession number for the $16 \mathrm{~S} \mathrm{rDNA}$ sequence of the type strain is Y08102.

Comments. Two strains known as Chlorobium limicola subsp. thiosulfatophilum, DSM 249 and strain 1430, belong to group 4 of the green sulfur bacteria according to Alexander et al. (2002). They have a significantly higher DNA G + C content $(58 \cdot 1 \mathrm{~mol} \%)$ than Chlorobium limicola, and cannot be considered to be subspecies of this species. They are considered to be strains of Chlorobaculum thiosulfatiphilum sp. nov.

\section{Description of Chlorobaculum parvum sp. nov.}

Chlorobaculum parvum (par'vum. L. neut. adj. parvum small).

Cells are curved rods or vibrioid, $0 \cdot 7-1 \cdot 1 \mu \mathrm{m}$ wide, nonmotile and occur as single cells. Colour of cell suspensions is green, and photosynthetic pigments are BChl $d$ with chlorobactene as the major carotenoid. Photoautotrophic growth occurs with sulfide, sulfur and thiosulfate as photosynthetic electron donors; molecular hydrogen may be used by some strains. In the presence of sulfide and bicarbonate, some simple organic compounds are photoassimilated. Vitamin $B_{12}$ may be required for growth. Brackish water and marine bacteria that require at least $1 \%$ $\mathrm{NaCl}$. The DNA G $+\mathrm{C}$ content is $56 \cdot 1-56 \cdot 6 \mathrm{~mol} \%$.

The type strain is DSM $263^{\mathrm{T}}$. The GenBank/EMBL accession number for the 16S rDNA sequence of the type strain is Y10647.

Comments. Two strains, known as Chlorobium vibrioforme subsp. thiosulfatophilum DSM 263 (NCIB 8327, also referred to as Chlorobium limicola subsp. thiosulfatophilum) and NCIB 8346, are genetically closely related to each other but different from other known species. They have a characteristically high DNA G + C content $(56 \cdot 1$ and $56.6 \mathrm{~mol} \%$, respectively) and require salt for optimum growth. They are phylogenetically distant from the type 
strain of Chlorobium vibrioforme and belong to group 4 of the green sulfur bacteria, according to Alexander et al. (2002).

\section{Description of 'Chlorobaculum chlorovibrioides' comb. nov.}

Basonym: Chlorobacterium chlorovibrioides Gorlenko et al. 1974.

The species description is as given by Pfennig \& Overmann (2001a) for Chlorobium chlorovibrioides. Cells are curved rods or vibrioid, $0 \cdot 3-0 \cdot 4 \mu \mathrm{m}$ wide, non-motile and occur as single cells. Colour of cell suspensions is green and photosynthetic pigments are $\mathrm{BChl} d$ with chlorobactene as the major carotenoid. Photoautotrophic growth occurs, with sulfide and sulfur as photosynthetic electron donors. In the presence of sulfide and bicarbonate, some simple organic compounds are photoassimilated. Vitamin $B_{12}$ is required for growth. Brackish water and marine bacteria that require at least $2-3 \% \mathrm{NaCl}$ for optimal growth.

The type strain of Chlorobium chlorovibrioides, DSM 1377, is lost. A new type strain is currently not proposed. Strain UdG 6026 may qualify as such. The GenBank/EMBL accession number for the 16S rDNA sequence of this strain is Y10649.

Comments. The type strain of Chlorobium chlorovibrioides, DSM 1377 (DNA G $+\mathrm{C}$ content $54 \mathrm{~mol} \%$ ) has been lost, but a new isolate, UdG 6026, was assigned to this species (Figueras et al., 1997). This strain belongs phylogenetically to the genus Chlorobaculum and is closely related to Chlorobaculum parvum. It is proposed as the type strain of 'Chlorobaculum chlorovibrioides'. Based on $16 \mathrm{~S}$ rDNA sequence data, strain Chlorobium vibrioforme UdG 6043 is closely related to UdG 6026 and is regarded as an additional strain of this species.

\section{Acknowledgements}

Part of this work was supported by the INTERREG II programme of the European Union. The calculations for and the construction of the phylogenetic trees by B. Alexander (Institut für Meereskunde, Kiel) are gratefully acknowledged.

\section{References}

Alexander, B., Andersen, J. H., Cox, R. P. \& Imhoff, J. F. (2002). Phylogeny of green sulfur bacteria on the basis of gene sequences of $16 \mathrm{~S}$ rRNA and of the Fenna-Matthews-Olson protein. Arch Microbiol 178, 131-140.

Figueras, J. B., Garcia-Gil, L. J. \& Abella, C. A. (1997). Phylogeny of the genus Chlorobium based on $16 \mathrm{~S}$ rDNA sequence. FEMS Microbiol Lett 152, 31-36.

Gorlenko, V. M. (1970). A new phototrophic green sulfur bacterium. Prosthecochloris aestuarii nov. gen. nov. spec. Z Allg Mikrobiol 10, 147-149.

Gorlenko, V. M. (2001). Genus V. Prosthecochloris. In Bergey's Manual of Systematic Bacteriology, 2nd edn, vol. 1, pp. 617-620. Edited by D. R. Boone, R. W. Castenholz \& G. M. Garrity. New York: Springer.
Heising, S., Richter, L., Ludwig, W. \& Schink, B. (1999). Chlorobium ferrooxidans sp. nov., a phototrophic green sulfur bacterium that oxidizes ferrous iron in coculture with a "Geospirillum" sp. strain. Arch Microbiol 172, 116-124.

Imhoff, J. F. (1988). Lipids, fatty acids and quinones in taxonomy and phylogeny of anoxygenic phototrophic bacteria. In Green Photosynthetic Bacteria, pp. 223-232. Edited by J. M. Olson, J. G. Ormerod, J. Amesz, E. Stackebrandt \& H. G. Trüper. New York: Plenum.

Imhoff, J. F. (1999). A phylogenetically oriented taxonomy of anoxygenic phototrophic bacteria. In The Phototrophic Prokaryotes, pp. 763-774. Edited by G. A. Pescheck, T. W. Löffelhard \& G. Schmetterer. New York: Plenum.

Imhoff, J. F. \& Bias-Imhoff, U. (1995). Lipids, quinones and fatty acids of anoxygenic phototrophic bacteria. In Anoxygenic Photosynthetic Bacteria, pp. 179-205. Edited by R. E. Blankenship, M. T. Madigan \& C. E. Bauer. Dordrecht: Kluwer.

Lapage, S. P., Sneath, P. H. A., Lessel, E. F., Skerman, V. B. D., Seeliger, H. P. R. \& Clark. W. A. (editors) (1992). International Code of Nomenclature of Bacteria (1990 Revision). Bacteriological Code. Washington, DC: American Society for Microbiology.

Overmann, J. (2001). Green sulfur bacteria. In Bergey's Manual of Systematic Bacteriology, 2nd edn, vol. 1, pp. 601-605. Edited by D. R. Boone, R. W. Castenholz \& G. M. Garrity. New York: Springer.

Overmann, J. \& Tuschak, C. (1997). Phylogeny and molecular fingerprinting of green sulfur bacteria. Arch Microbiol 167, 302-309. Pelsh, A. D. (1936). Hydrobiology of Karabugaz Bay of the Caspian Sea. Tr Vses Nauchno-Issled Inst Gallurgii Leningrad 5, 49-126.

Pfennig, N. (1989). Green sulfur bacteria. In Bergey's Manual of Systematic Bacteriology, vol. 3, pp. 1682-1697. Edited by J. T. Staley, M. P. Bryant, N. Pfennig \& J. G. Holt. Baltimore: Williams \& Wilkins.

Pfennig, N. \& Overmann, J. (2001a). Genus I. Chlorobium. In Bergey's Manual of Systematic Bacteriology, 2nd edn, vol. 1, pp. 605-610. Edited by D. R. Boone, R. W. Castenholz \& G. M. Garrity. New York: Springer.

Pfennig, N. \& Overmann, J. (2001b). Genus IV. Pelodictyon. In Bergey's Manual of Systematic Bacteriology, 2nd edn, vol. 1, pp. 614-617. Edited by D. R. Boone, R. W. Castenholz \& G. M. Garrity. New York: Springer.

Puchkova, N. N. \& Gorlenko, V. M. (1982). A new green sulfur bacterium, Chlorobacterium chlorovibrioides nov. sp. Mikrobiologiya 51, 118-124 (in Russian); Microbiology (English translation of Mikrobiologiya) 51, 107-112.

Schmidle, W. (1901). Neue Algen aus dem Gebiete des Oberrheins. Beih Bot Zentbl 10, 179-180 (in German).

Szafer; W. (1911). Zur Kenntnis der Schwefelflora in der Umgebung von Lemberg. Bull Int Acad Sci Ser V Cracovie, 160-167 (in German).

Trüper, H. G. (1976). Higher taxa of the phototrophic bacteria: Chloroflexaceae fam. nov., a family for the gliding, filamentous, phototrophic "green" bacteria. Int J Syst Bacteriol 26, 74-75.

Wahlund, T. M., Woese, C. R., Castenholz, R. W. \& Madigan, M. T. (1991). A thermophilic green sulfur bacterium from New Zealand hot springs, Chlorobium tepidum sp. nov. Arch Microbiol 156, 81-90.

Wahlund, T. M., Woese, C. R., Castenholz, R. W. \& Madigan, M. T. (1996). Chlorobium tepidum sp. nov. In Validation of the Publication of New Names and New Combinations Previously Effectively Published Outside the IJSB, List no. 59. Int J Syst Bacteriol 46, 1189-1190.

Witt, D., Bergstein-Ben Dan, T. \& Stackebrandt, E. (1989). Nucleotide sequence of $16 \mathrm{~S}$ rRNA and phylogenetic position of the green sulfur bacterium Clathrochloris sulfurica. Arch Microbiol 152, 206-208. 